\title{
Modification of Darcy's Law and Hydraulic Conductance Equation
}

\author{
Ezz El-Din El-Tablawi* \\ Hydrology Department, Desert Research Center, Cairo P.O.B. 11753 Egypt
}

\section{A R T I C L E I N F O}

Article history:

Received 31 October 2012

Accepted 26 November 2012

\section{Keywords:}

Tortuosity;

Hydraulic conductance;

Porosity;

Modified darcy.

\begin{abstract}
A B S T R A C T
General Head Boundary package in MODFLOW computer program has a vital importance for the transient flow simulation in the groundwater model. It involves two important parameters; head on boundary and hydraulic conductance. The present study aims to modify the flow and hydraulic conductance equations for groundwater model boundaries and volumetric flux. The following two hydrogeological factors are suggested in the equations; Porosity and Tortuosity, which control essentially the flow channels within the rock materials or into subsurface zones filled with sedimentary deposits. The obtained results indicate that the volumetric flux is the product of the following parameters; hydraulic conductivity, area of the cell faces normal to the flow direction, decline of head, porosity divided by the length of the flow path (distance between nodes) and tortuosity. The study indicates that the hydraulic conductance in the groundwater model boundaries with uniform grid is the product of the transmissivity and porosity divided by the tortuosity. While for non-uniform grid, the hydraulic conductance is the product of the hydraulic conductivity, the porosity and the cross-sectional area of flow divided by the length of the flow path (in this case, the distance between the nodes) and the tortuosity. The suggested two factors were neglected in the previous literatures and omitted in the application of the MODFLOW computer program.
\end{abstract}

\section{Introduction}

The present paper deals with the study of the groundwater boundaries with respect to the flow into or out the boundary. Boundary conditions represent the mathematical statements specifying the dependant variables (head) or the derivative of the dependant variables (flux) at the boundaries of the problem domain. The flow and hydraulic conductance equations for groundwater model boundaries and volumetric flux are modified and adopted in the present work in order to calculate the flow from cell to cell and the conductance from head source to the aquifer with sedimentary materials or other rock materials. The flow and hydraulic approaches received the attentions of number of workers in the field of modeling. Among them are; Bear and Verruijt [1], Mc Donald and Harbough [2], Anderson and Woessner ${ }^{[3]}$, ACSAD ${ }^{[4]}$, ACSAD and $\mathrm{DRC}^{[5]}$ and ACSAD ${ }^{[6]}$. Hydaulic conductance equation is used in both the General Head Boundary package in MODFLOW computer program of different versions and the volumetric flux equation in MODFLOW comp-

* Corresponding author.

E-mail address: Ezz1960@hotmail.com

\section{uter program.}

\section{DISCRETIZATION CONVENTION}

Figure 1 shows a spatial discretization of a groundwater aquifer system with mesh of blocks called cells. The location of which are described in terms of rows, columns and layers. An i, j, k indexing system is used.

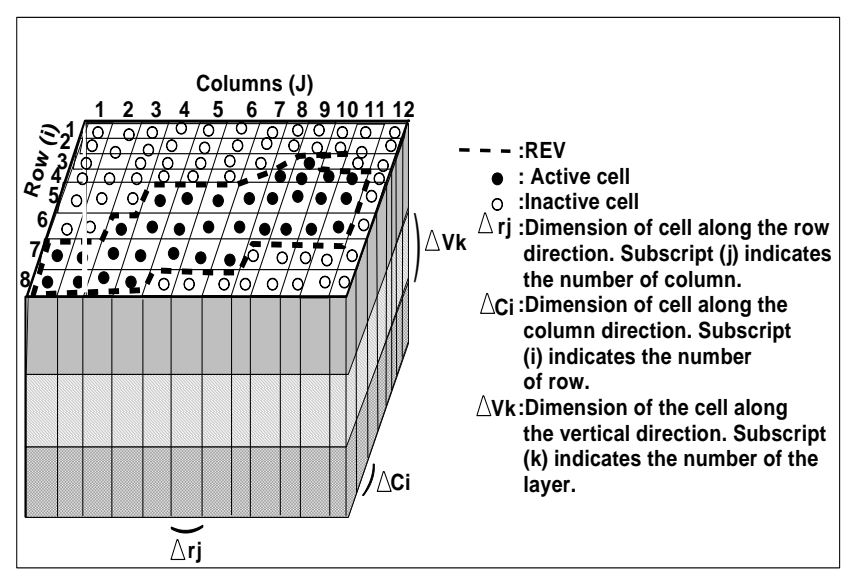

Fig. 1: Discretized groundwater aquifer system. 
For system consisting of "n row" rows, "n col" columns, and "n layers", $i$ is the row index, $i=1,2,3 \ldots . . n$ row; $j$ is the column index, $\mathrm{j}=1,2,3, \ldots . \mathrm{n}$ column; $\mathrm{k}$ is the layer, $\mathrm{k}=1,2 \ldots . \mathrm{n}$ layer.

\section{HYDROGEOLIGICAL BACKGROUND}

For example, Fig. 1 shows as system with $\mathrm{n}$ row $=8, \mathrm{n}$ column $=12$ and $n$ layer $=3$. Rows would be considered parallel to the $\mathrm{x}$ axis, so that increments in the row index. i, would correspond to decreases in $\mathrm{y}$; and columns would be considered parallel to the y axis, so that increments in the column index $\mathrm{j}$, would correspond to increases in $\mathrm{x}$. These conventions are followed in constructing Fig. 1. However, applications of the model requires only that rows and columns fall along consistent orthogonal directions within the layers, and does not require the designation of $\mathrm{x}, \mathrm{y}$, or $\mathrm{z}$ coordinate axis. Following the conventions used in Fig. 1, the widely cells in the row direction, at a given column, $j$, is designated $\Delta_{\mathrm{rj}}$. The width of the cells in the column direction at given row (i) is designated $\Delta_{\mathrm{ci}}$ and the thickness of the cell in a given layer $(\mathrm{k})$ is designated $\triangle \mathrm{Vk}$. Within each cell there is a point called a "node" at which head is calculated. The dashed line (---- REV) is the representative elementary volume. It is a universal average volume; where it is a certain range of averaging volumes that corresponds to the range of variation in sizes ${ }^{[7]}$. These averaging volumes are considered as sum of AEV (Arbitrary Elementary Volume). They represent the samples of sufficiently large volume, taken at different places within the domain which always contain a solid phase. The domain is an aquifer occupied by porous medium (solid matrix and void space occupied by one or more fluid phase).

\section{GENERAL HEAD BOUNDARY}

The function of the general-head boundary (GBH) package in MODFLOW computer program is that flow into or out the cell $\mathrm{i}, \mathrm{j}, \mathrm{k}$, from external source is provided in proportion to the differences between head in the cell, hi, $\mathrm{j}, \mathrm{k}$, and the head assigned to the external source, hbi, j, k. Thus a linear relationship between flow into the cell and head in the cell is established ${ }^{[2]}$ :

$$
Q_{b i, j, k}=C_{b i, j, k}\left(h_{b i, j, k}-h_{i, j, k}\right)
$$

where:

$Q_{b i, j, k}:$ Is the flow into cell $\mathrm{i}, \mathrm{j}, \mathrm{k}$ from source.

$C_{b i, j, k}:$ Is the conductance between the external source and cell $\mathrm{i}, \mathrm{j}, \mathrm{k}$.

$h_{b i, j, k}:$ Is the head assigned to the external source.

$h_{i, j, k}:$ Is the head in the cell $\mathrm{i}, \mathrm{j}, \mathrm{k}$.

The relationship between cell i,j,k and external source is plotted schematically in Fig. 2.

The constant-head source is represented by the apparatus on the right in Fig. 2, which holds the source head at the level $h_{b}$. The link between the source and the cell i.j,k is represented by block of porous material $C_{b i, j, k}$

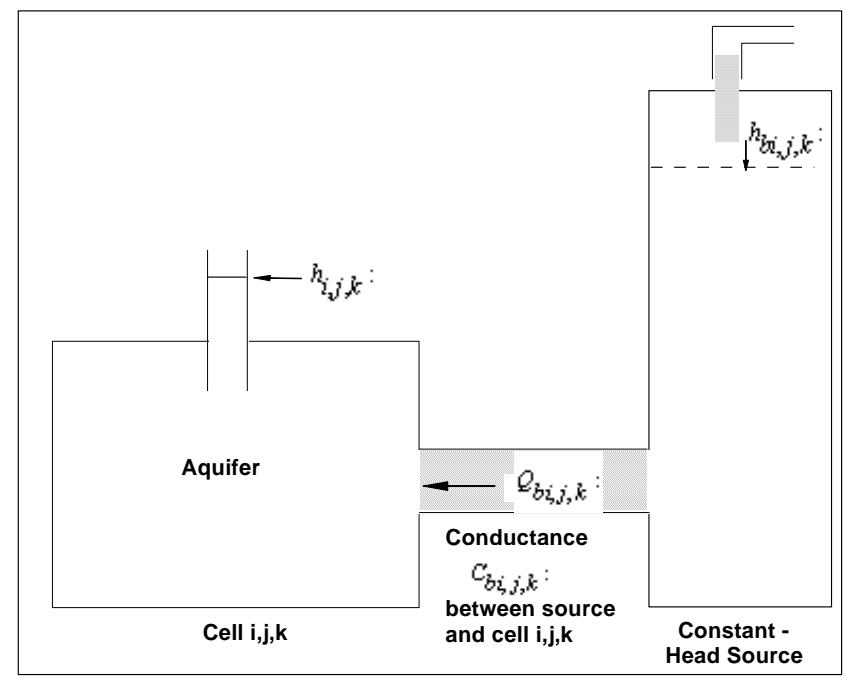

Fig. 2: Schematic diagram illustrating principle of general-head boundary package in MOFLOW computer program (after ${ }^{[2]}$ ).

\section{HYDRAULIC CONDUCTANCE EQUATION}

Flow into cell $\mathrm{i}, \mathrm{j}, \mathrm{k}$ in the row direction from cell $\mathrm{i}, \mathrm{j}-1, \mathrm{k}$ (Fig. 3), is given by Darcy's law ${ }^{[2]}$ as following:

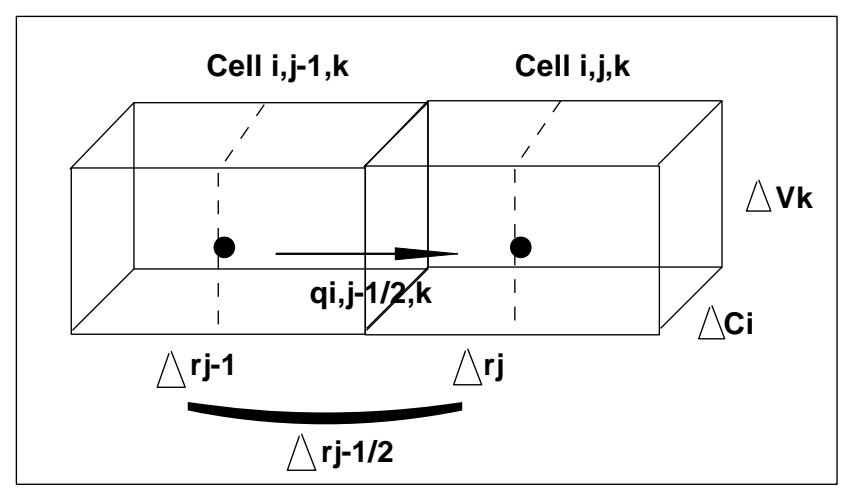

Fig. 3: Flow into cell i, j, k from cell i, j-l, k..

$$
q_{i, j-1 / 2, k}=K R_{i, j-1 / 2, k} \Delta C i \Delta V k \frac{\left(h_{i, j-1, k}-h_{i, j, k}\right)}{\Delta r_{j-1 / 2}}
$$

Where :

$q_{i, j-1 / 2, k}$ : Is the volumetric fluid discharge through the face between cells i,j,k and i,j-1,k ( $\mathrm{m}^{3} /$ day).

$K R_{i, j-1 / 2, k}$ :Is the hydraulic conductivity along the row between nods i,j,k and i,j-1,k (m/day).

$C i \Delta V k .:$ Is the cross sectional area of the cell faces normal to the row direction $\left(\mathrm{m}^{2}\right)$

$h_{i, j, k}:$ Is the head at node $\mathrm{i}, \mathrm{j}, \mathrm{k}(\mathrm{m})$.

$h_{i, j-1, k}$ : Is the head at node $\mathrm{i}, \mathrm{j}-1, \mathrm{k}(\mathrm{m})$.

$\Delta r_{j-1 / 2}$ : Is the distance between nodes $\mathrm{i}, \mathrm{j}, \mathrm{k}$ and $\mathrm{i}, \mathrm{j}-1, \mathrm{k}$ (m). 
The hydraulic conductance is the product of hydraulic conductivity and cross-sectional area of flow divided by the length of the flow path ( in this case, the distance between the nodes) as follows ${ }^{[2,4-6]}$.

$$
C R_{i, j-1, k}=K R_{i, j-1 / 2, k} \frac{\Delta C i \Delta V k}{\Delta r_{j-1 / 2}}
$$

Where :

$C R_{i, j-1, k}$ : Is the hydraulic conductance ( $\mathrm{m}^{2} /$ day). $K R_{i, j-1 / 2, k}:$ Is the hydraulic conductivity (m/day). $\Delta V k:$ Is the thickness of layer $(\mathrm{m})$.

$\Delta C i$ : Is the width of layer (m).

$\Delta r_{j-1 / 2}$ : Is the distance between nodes (m).

\section{AQUIFER THICKNESS}

The thickness of the aquifer in an open pipe $(L)$, while the thickness of an aquifer filled with sedimentary or other rock materials ( $L \theta$ ) Where $\theta$ is the effective porosity ${ }^{[8]}$. The cross-sectional area of flow in the open pipe is $A$. While it is $(A \theta)$ in sedimentary or other rock materials. Any fluid particle moving in an open pipe must travel across a distance $(L)$, while any fluid particle moving through sand section must travel distance $L \theta$. Since the flow path must necessarily involve a tortuous movement around the sand grain. Thus the crossed distance must divide by its tortuosity $\left(\frac{L}{\tau}\right)^{[7]}$. Consequently any thickness of an aquifer filled with any sedimentary or rock materials must multiplied by the effective porosity $(\theta)$ and divided by the tortuosity $(\tau)$ by the following equation:

$$
H=\frac{L \theta}{\tau}
$$

Where :

$H$ : Is the thickness of groundwater aquifer (m).

$L:$ Is the thickness in an open pipe (m)

$\theta$ :Is the effective porosity of the sedimentary or any rock materials (dimensionless).

$\tau$ :Is the tortuosity (dimensionless).

\section{FLOW THROUGH CONDUITS}

In flow through conduits, the Reynolds number (Re), which is a dimensionless number expressing the ratio of inertial to viscous forces acting on the fluid, is used as a criterion to distinguish between laminar flow occurring at low velocities and turbulent flow occurring at higher velocities. The critical value of Re between laminar and turbulent flow in pips is around 2000. By analogy, a Reynolds number is defined also for flow through porous media :

$$
\operatorname{Re}=\frac{q d}{v} \text { [1] }
$$

Where $d$ is some representative microscopic length (m) characterizing the solid matrix, $v$ is the kinematic viscosity of the fluid around $1 \times 10^{-6} \mathrm{~m}^{2} / \mathrm{sec}$ or $8.64 \times 10^{-2}$ $\mathrm{m}^{2} /$ day (corresponding to water at $20^{\circ} \mathrm{C}$ ) and $q$ is the specific discharge. ${ }^{q}$ is calculated from the following equation:

$$
q=V \quad \mathrm{X} \quad \mathrm{n} \quad(\mathrm{m} / \mathrm{day}){ }^{[1]}
$$

Where;

$V$ : Is the velocity of the fluid (m/day).

$\mathrm{n}$ : Is the effective porosity (dimensionless).

By analogy to the Reynolds number for pipe, $d$ should be a length representing the cross-section of an elementary channel of porous medium. Often the mean grain diameter is taken as the length dimension $d$ in equation (6). $d$ can be calculated form the following equation:

$$
d=\left(\frac{k}{n}\right)^{1 / 2}
$$

Where;

$\mathrm{k}$ : Is the intrinsic permeability $\left(\mathrm{m}^{2}\right)$. It is a function only of the porous medium.

Also $d$ denotes a characteristic length of the microscopic geometry of the void space ${ }^{[9]}$. The length $d$ represents the scale of microscopic inhomogeneity of the void space.

Darcy's law is valid as long as the Reynolds number does not exceed some value between 1 and 10. Most groundwater flows occur in this range, except in the very close vicinity of large pumping and recharging wells, or large spring. Large Reynolds number may also be observed in very porous aquifers such as cavernous limestone.

\section{TORTUOSITY}

Tortuosity of porous medium is defined as the length of the sample of porous medium divided by the length of tortuous flow path which is being traveled by the fluid particle through the sample ${ }^{[10]}$. The tortuosity $(\tau)$ is essentially an empirical factor. Its values range between about 0.5 and $0.01^{[11]}$. While De Mersily ${ }^{[12]}$ gives a range of tortuosity from 0.1 for clay and 0.7 for sand.

The tortuosity $(\tau$ ) can be calculated by the following equation ${ }^{[1]}$ :

$$
\begin{aligned}
& T_{i j}^{*}=\frac{1}{U_{\theta w}} \int_{\left(S_{w w}\right)}\left(X_{i}-X_{o j}\right) v_{i} d S \quad \text { where, } \\
& S=\frac{\Delta U_{w}}{A \Delta h} \\
& \text { and } S=\frac{\Delta U_{w}}{A \Delta \Phi}
\end{aligned}
$$

For an isotropic porous medium $T_{i j} *$ is reduced to:

$$
\begin{aligned}
& T_{i j}^{*}=\frac{\theta_{w}^{s}}{\theta_{w}} \delta_{i j} \quad \text { where, } \\
& \theta_{w}^{s}=\frac{S_{w w}}{S_{o}} \\
& \text { and } \theta_{w}=\frac{U_{\theta_{w}}}{U_{o}}
\end{aligned}
$$


Where:

$T_{i j}^{*}$ : Is referred to a tortuosity defined by Bear and Bachmat ${ }^{[13,14]}$. It is a second-rank symmetric tensor that expresses the effect of the configuration of water occupied portion of the REV (Representative Elementary Volume).

$U_{\theta_{v}}$ : Denotes the volume occupied by water within the REV.

$S_{w w}$ : Denotes the water-water portion of bounding surface of the REV.

$X_{o}$ : Is the centroid of the REV.

$v_{i}$ : Is the kinematic viscosity of the fluid. It is the outwardly directed normal to the surface $S_{w w}$.

$S$ : Is the storativity of phereatic or confined aquifers.

In spite of the similarity in the two definitions, the storativity in each of the two types of the aquifer has different reasons. In the confined aquifer, it is the outcome of water and matrix compressibility. While in the phereatic aquifer, water is mostly drained from the pore spaces between the initial and final positions of phereatic surface. The storativity of a phereatic aquifer, is therefore referred to as specific yield $\left(s_{y}\right)$; it gives the yield of an aquifer per unit area and per unit drop of the water table.

$\Delta U_{w}$ :Is the volume of water released from storage (or added to it) per unit horizontal area $(A)$, of an aquifer and per unit decline (or rise) of piezometric head ( $\Phi$ ). $\Delta h:$ Is the decline of phereatic surface. $\Delta \Phi$ : Is the decline of piezometric surface.

$A$ : Is the cross-sectional area.

$\theta_{w}:$ Is the prescribed water content (or piezometric pressure head $\Phi_{w}$,

$P_{w}$, or suction $(\psi)$ at all points of the boundary

$$
\begin{aligned}
& =\frac{\text { Volume of water in REV }}{\text { Volume of REV }}: 0 \leq \theta_{w} \leq n, \text { and } \theta_{w}=n S_{w} \\
& S_{w}=\frac{\text { Volume of water in REV }}{\text { Voulem of Void in REV }}: 0 \leq S_{w} \leq 1
\end{aligned}
$$

Where $n$ is the porosity at the considered point. $U_{o}$ : Is the pore volume of the column.

The pore volume $\left(P_{v}\right)$ can be calculated by the following equation for the isotropic medium ${ }^{[8]}$ :

$$
P_{v}=L \theta A
$$

While, according to El Tablawi ${ }^{[7]}, L$ must divided by $\tau$. Then the pore volume for the anisotropic medium is defined by the following equation :

$P_{v}=\frac{L}{\tau} \theta A$
Where :

$L:$ Is the thickness in case of an open pipe (m).

$\theta:$ Is the effective porosity (dimensionless).

$\tau$ : Is the totuosity(dimensionless).

$S_{o}$ : Is the specific storativity (the total released volume of water $\Delta U_{w}$ from storage in the aquitard per unit horizontal area up to time $\mathrm{t}$ ).

$\delta i_{i j}$ :Is the Kroenecker delta $=$ The ratio of the length characterizing the individual pores of porous medium to the length characterizing their cross-section.

\section{POROSITY}

The porosity of the soil or rock material is the percentage of the total volume of the material to the volume which is occupied by pores or interstices. These pores may be saturated if the material is saturated with air and for water or may be unsaturated ${ }^{[15]}$. For soil or other unconsolidated material, such samples can be obtained with one of the various techniques developed for this purpose ${ }^{[16]}$. If the material is consolidated, a drilled core sample is used. The total volume Vt of the undisturbed sample is determined. The sample is ovendried to remove the water $\left(24\right.$ hours at $105^{\circ} \mathrm{C}$ is usually sufficient) and the dry weight $\mathrm{Wd}$ is determined. Dividing Wd by the density of the soil or rock material gives the volume Vs of the solid phase of the sample. The porosity $\mathrm{n}$ is then calculated as ${ }^{[15]}$ :

$$
n=\frac{V_{t}-V_{s}}{V_{t}} 100(\%)
$$

The density of the solid depends on the mineral composition of the soil or rock. For soils and gravel the density of $2650 \mathrm{~kg} / \mathrm{m}^{3}$ is commonly used as the density of the solid phase ${ }^{[17]}$. Densities of rock material, such as limestone and granite, are usually in the range of 2700 to $2800 \mathrm{~kg} / \mathrm{m}^{3}$. Basalt may have a density close to 3000 $\mathrm{kg} / \mathrm{m}^{3}$.

The porosity of a granular medium with spherical, uniform particle can be calculated as 47.6 percent if the spheres are packed loosely in a cubical array, and as 26.0 percent if the spheres are packed densely in a rhombohedra array.

Porosity can be calculated from the void ratio. The void ratio is the term more commonly used in soil mechanics to express the pore volume of the soil. It is defined as the ratio between the volume of the void $\mathrm{Vv}$ and the volume of the solid Vs. Its symbol is usually (e). Thus $e=\frac{V_{v}}{V_{s}}$.

The value of e varies from about 0.7 for dense sands and gravel to about 1.3 for unconsolidated clays. The relation between porosity (n) and the void ratio (e) is:

$$
n=\frac{e}{e+1}{ }^{[15]}
$$


Porosity $(\theta)$ is approximately equals to specific yield $\left(S_{v}\right)$ and specific retention $\left(S_{r}\right)$ in the following equation for the different rock units as tabulated by Hazel ${ }^{[18]}$ and El Tablawi ${ }^{[7]}$ :

$$
S_{r}=\theta-S_{y}
$$

Where:

$S_{r}$ : Is the specific retention (dimensionless).

$\theta$ : Is the porosity (dimensionless).

$S_{y}$ : Is the specific yield (dimensionless).

The specific yield of an aquifer is the volume of water which will drown under gravity from a unit volume of aquifer. For a section of an aquifer, it is the ratio of the drainable water to the saturated volume. For the unconfined aquifer, the specific yield ranges from about 0.1 to $0.3^{[18]}$. While the specific retention is the volume of water retained when the specific yield volume has been released ${ }^{[18]}$.

$S_{y}(<\mathrm{n})$ is sometimes called effective porosity ${ }^{[1]}$.

Figure 4 shows typical relationships between $S_{y}, S_{r}$ and particle size.

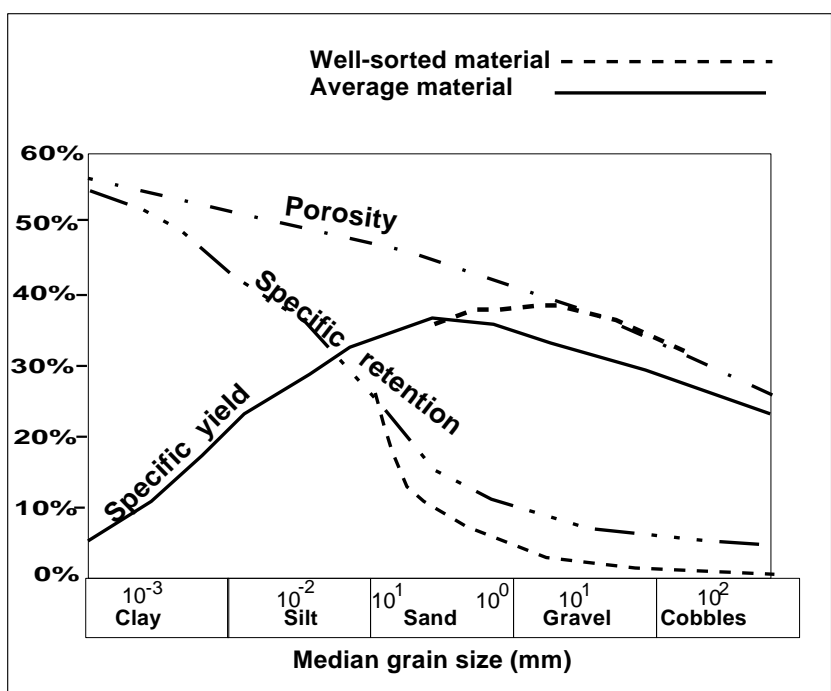

Fig. 4: Relationship between specific yield and grain size (from Conkling et al. ${ }^{[19]}$, as modified by Davis and De Wiest ${ }^{[20]}$ ).

\section{PRESENT MODIFICATION OF THE FLOW AND HYDRAULIC CONDUCTANCE EQUATIONS}

In the present work, the volumetric flux of Dracy's law (equation, 2) is modified and adopted for groundwater aquifer system as follows:

$$
q_{i, j-1 / 2, k}=K R_{i, j-1 / 2, k} \Delta C i \Delta V k \frac{\left(h_{i, j-1, k}-h_{i, j, k}\right)}{\Delta r_{j-1 / 2}}\left(\frac{\theta}{\tau}\right)
$$

The hydraulic conductance (equation, 3 ) for non uniform groundwater model grid is modified and adopted as follows:

$$
C R_{i, j-1, k}=K R_{i, j-1 / 2, k} \frac{\Delta C i \Delta V k}{\Delta r_{j-1 / 2}}\left(\frac{\theta}{\tau}\right)
$$

The hydraulic conductance (equation, 3) for the uniform groundwater model grid is modified and adopted as follows:

$$
C R_{i, j-1, k}=K R_{i, j-1 / 2, k} \Delta V k\left(\frac{\theta}{\tau}\right)
$$

If the transmissivity ( $\mathrm{T}$ ) for the uniform groundwater model grid is defined by the equation:

$$
T=K R \Delta V k
$$

Then the final form of equation for the hydraulic conductance (23) for uniform groundwater model grid is modified to the following equation:

$$
C R=T \frac{\theta}{\tau}
$$

Where:

$T:$ Is the transmissivity ( $\mathrm{m}^{2} /$ day).

$C R:$ Is the hydraulic conductance $\left(\mathrm{m}^{2} /\right.$ day).

$\theta:$ Is the effective porosity (dimensionless).

$\tau:$ Is the tortuousity (dimensionless)

The present modification of the two equations considers the importance of both the porosity and tortuosity for the proper determination of the hydraulic conductance and the flow equations.

\section{Example:}

A groundwater aquifer consists of sand, gravely sand and clay at one locality in the area of west El Nubariya canal in Egypt. The aquifer having hydraulic conductivity of $43 \mathrm{~m} /$ day, an effective porosity of 0.24 , aquifer width of $17400 \mathrm{~m}$, aquifer thickness of $105 \mathrm{~m}$ and hydraulic gradient of $0.0019^{[21-22]}$. Assuming the tortuosity of such aquifer reaches to 0.4 in an average according to values of tortuosity for sand and clay by De Mersily ${ }^{[12]}$. The annual recharge of such aquifer will be $149265.9 \mathrm{~m}^{3} /$ day by applied Dracy's law (equation, 2). While the actual annual recharge by applied modified Darcy by the author (equation, 21) will be $89559.54 \mathrm{~m}^{3} /$ day.

\section{RECOMENDATION}

It is recommended to consider the equations (2) and (3) for the determination of the flow in the open pipe. While the flow in pipe filed with sedimentary or rock materials, the equations (21), (22) and (25) are considered in order to give accurate solution. It is important to modify the MODFLOW program with different versions by introducing the equation (21) in the program instead of the equation (2) in order to obtain the proper determinations.

\section{ACKNOWLEDGMENT}

Praise to GOD, lord of the worlds, by the grace of whom the implementation of this work was possible.

\section{References}

1) Bear J. and Verruijt A. (1987). "Modeling Groundwater Flow and Pollution", D. Reidel Publishing Company, ordecht, Holland, 414p. 
2) Mc Donald and Harbough (1988). "A Modular Three-Dimesional Finite-Difference Groundwater Flow Model", Techniques of Water Resources Investigations of the United State Geological Survey, Book 6, Chapter A1, Modeling techniques.

3) Anderson M.P. and Woessner W.W. (1992). "Applied Groundwater Modeling Simulation of Flow and Advective Transport", Academic Press. Inc San Diego, New York Boston, Landon, Sydney Tokyo Toronto, 381p.

4) Arab center for studies and arid zones and dry land (ACSAD) (1998). "The Mathematical Model of Sabkhet Al- Mouh", ACSAD. W.S./R92/ Damascus (in Arabic), 189p.

5) Arab center for studies and arid zones and dry land and Desert research center (ACSAD and DRC) (1998). "The Mathematical Model for El Sheikh Zowied-Rafah, North Sinai, Egypt", ACSAD. W.S./R123/ Damascus (in Arabic), 234p.

6) Arab center for studies and arid zones and dry land and (ACSAD) (2002). "The Mathematical Model of El-Zabadani Basin”, ACSAD. H.S./R156/ Damascus (in Arabic), 191p.

7) El Tablawi E. (2012). "Groundwater Contaminant Transport”, Handbook, Theoretical and Mathematical Background and Modeling Environment, Setting Number in the Egyptian General Book Authority( Books House) $16246 / 2012$ Cairo, Egypt, 106p.

8) Zheng C. and Benett G.D. (2002). "Applied Contaminant Transport Modeling", Second Edition, John Wiley and Sons, Inc. New York, 621p.

9) Bear J., Tsang C. and De Mersily G. (1993). "Flow and Contaminant Transport in Fractured Rock" Academic Press, Inc, 1250 Sixth Avenue, San Diago, California 92101-4311, 560p.

10) Bear J. (1972). "Dynamic of Fluid in Porous Media", Elsevier, New York, 764p.

11) Freeze R.A. and Cherry A.J. (1979). "Groundwater", Prentice Hall, Englewood Cliffs, NJ. 604 p.
12) De Marsily G. (1986). "Quantitative Hydrogeology: Groundwater Hydrology for Engineers", Academic Press, San Diego, 440 p.

13) Bear J. and Bachmat Y. (1984). "Transport Phenomena in Porous Media", Basic Equation in $\mathrm{J}$. Bear and M.Y, Corapcioglu (eds). Fundamentals of Transport Phenomena in Porous Media, Martinus Nijhoff, Dordrecht, pp. 3-61.

14) Bear J. and Bachmat Y. (1986). "Macroscopic Modeling of Transport Phenomena in Porous Media. 2", Application to Mass, Momentum and Energy Transport, Transport in Porous Media 1, 241 - 269.

15) Bouwer H. (1978). "Groundwater Hydrology", McGraw-Hill, Inc All Right Reserved Printed In the United States of America.137 p.

16) Reeve R.C. (1957). "Measurement of Permeability in the Laboratory", In "Drainage of Agricultural Lands" J. N. Luthin (ed), Agronomy Monograph No. 7, Am. Soc. Agron., Madison, Wis., pp 414-419.

17) Baver L.D., Gardner W.H., and Gardner W.R. (1972). "Soil Physics, $4^{\text {th }}$ ed. JohnWily and Sons, New York, 498p.

18) Hazel C.P. (1975). "Groundwater Hydraulic", Lectures of Irrigation and Water Supply Commission, Queens Land to the Australian Water Resources Council's, Groundwater School, August.

19) Conkling H. et al. (1934). "Ventura County Investigation", California Div. Water Resour. Bull. 6, 244p.

20) Davis S.N. and De Wiest R.J.M. (1966). "Hydrology", Wiley, New York.

21) El Tablawi E. (2002). "Groundwater Management for Agricultural Development in Some Areas-West of Nubariya and South of El-Nasr Canals", Ph.D. Thesis, Institute of Environmental Studies and Research, Ain Shams University, Egypt. 229p.

22) El Tablawi E. (2008). "Study of Water Quality Changes With Groundwater Movement Using Mathematical Modeling Technique, South of El-Nasr Canal, East of Cairo-Alexandria Desert Road, Egypt.", Ain Shams University, Journal of the Faculty of Education, Science Section, Vol. 32, pp 747. 